\title{
Investigasi Kapabilitas Inovasi Teknologi pada Industri Alas Kaki di Jawa Timur
}

\author{
Esti Dwi Rinawiyanti \\ Universitas Surabaya \\ Benny Lianto \\ Universitas Surabaya \\ estidwi@staff.ubaya.ac.id
}

\begin{abstract}
Abstrak
Sebagai salah satu sektor manufaktur yang diprioritaskan untuk dikembangkan, industri alas kaki perlu meningkatkan keunggulan kompetitifnya dengan melakukan kapabilitas inovasi teknologi. Studi ini bertujuan untuk menilai kapabilitas inovasi teknologi industri alas kaki menengah dan besar di Jawa Timur. Survei dengan kuesioner dilakukan pada anggota Asosiasi Persepatuan Indonesia Jawa Timur. Data yang dikumpulkan dari 30 responden menggambarkan bahwa empat dimensi kapabilitas inovasi teknologi mendapatkan nilai ratarata di kategori tinggi, yaitu manufacturing capability, organization capability, strategic planning capability dan $R \& D$ capability. Beberapa perbaikan disarankan untuk tiga dimensi dengan nilai rata-rata di kategori sedang, meliputi learning capability, marketing capability dan resource allocation capability. Hasil uji MANOVA menunjukkan bahwa usia perusahaan mempengaruhi kapabilitas inovasi teknologi. Hasil uji crosstab menyatakan bahwa perusahaan yang telah lama beroperasi mempunyai kapabilitas inovasi teknologi yang lebih baik di beberapa variabel dibandingkan dengan perusahaan yang belum lama beroperasi. Hasil temuan dari studi ini diharapkan dapat memotivasi industri alas kaki untuk memperbaiki kapabilitas inovasi teknologi mereka supaya keunggulan kompetitif mereka meningkat dan mampu bersaing di pasar domestik maupun global.
\end{abstract}

Kata kunci: keunggulan kompetitif, TIC, usia perusahaan

\section{Pendahuluan}

Industri alas kaki merupakan salah satu sektor manufaktur unggulan dengan kontribusi yang signifikan bagi perekonomian nasional (Nurdin, 2019). Industri alas kaki merupakan sektor padat karya, berorientasi ekspor dan mengalami pertumbuhan yang terus meningkat (Nurdin, 2019). Industri alas kaki di Indonesia berjumlah 18.687 unit usaha yang meliputi 18.091 usaha kecil, 441 usaha menengah dan 155 unit usaha skala besar. Sejauh ini industri alas kaki dapat menyerap 795.000 orang (Wardani, 2019). Di tahun 2018, pertumbuhan industri alas kaki mencapai 9,42\%, meningkat signifikan dibandingkan tahun 2017 yang berkisar 2,22\%. Dengan pencapaian yang melampaui pertumbuhan ekonomi nasional sebesar 5,17\%, industri alas kaki mempunyai prospek yang cerah (Indonesia, 2019; Kemenperin, 2019; Nurdin, 2019).

Di tahun 2018, industri alas kaki nasional memproduksi 1,41 miliar pasang alas kaki atau sekitar 4,6\% dari total produksi alas kaki dunia, yang menempatkan Indonesia berada di peringkat empat besar produsen alas kaki di dunia setelah China, India, dan Vietnam (Kemenperin, 2019; Nurdin, 2019). Selain itu, Indonesia merupakan negara konsumen sepatu terbesar keempat dengan konsumsi 886 juta pasang alas kaki (Wardani, 2019). Hal tersebut membuktikan bahwa produk alas kaki dari Indonesia mampu bersaing di pasar domestik 
maupun global. Oleh karena itu, pengembangan industri alas kaki diutamakan dan dipersiapkan untuk memasuki era industri 4.0 agar lebih mempunyai keunggulan kompetitif global (Kemenperin, 2019).

Meskipun demikian, industri alas kaki mendapatkan ancaman dari produk impor. Sejak tahun 2010, diberlakukan perjanjian perdagangan bebas antara Association of Southeast Asian Nations (ASEAN) dan China, ASEAN-China Free Trade Agreement (ACFTA), yang memudahkan produk China masuk ke negara-negara anggota ASEAN. Misalnya, sebagian besar produk China dikenai tarif nol persen untuk masuk ke Indonesia. Hal ini jelas memberikan dampak yang serius pada produsen lokal (Karba'a, 2010). Industri alas kaki juga merupakan salah satu sektor yang paling rentan terpengaruh oleh Masyarakat Ekonomi Asean (MEA) yang diterapkan sejak tahun 2015 (Aria, 2016). Saingan terberat saat ini adalah Vietnam, yang mengalami kenaikan ekspor $10.5 \%$ di tahun 2018 dan menguasai $12 \%$ pasar sepatu di Uni Eropa, sedangkan Indonesia baru 4\% (Kemenperin, 2019).

Industri alas kaki tersebar di wilayah Jawa Barat, Jawa Timur, Jawa Tengah, Riau, Sumatera Barat dan DKI Jakarta (Kemenperin, 2003). Di Jawa Timur khususnya, industri alas kaki merupakan salah satu sektor industri yang dikembangkan dan diprioritaskan (Disperindag, 2011; Hasanah, 2019) karena berkontribusi signifikan pada perekonomian regional (Ferdyansyah, 2013) dan sebagai penyumbang ekspor terbesar kedua setelah DKI Jakarta (Widarti, 2019). Akan tetapi, industri alas kaki di Jawa Timur saat ini semakin tertekan karena berbagai faktor, seperti tingkat produktivitas yang rendah dengan upah yang tinggi, persaingan di pasar global, hingga industri pendukung (Widarti, 2019). Di samping itu, industri alas kaki Jawa Timur juga menghadapi persaingan yang ketat dari negara-negara produsen alas kaki, seperti China, India dan Vietnam (Editor, 2017). Oleh karena itu, industri alas kaki di Jawa Timur perlu meningkatkan keunggulan kompetitif, baik di tingkat domestik dan global, yang bisa dilakukan melalui inovasi dan teknologi.

Aktivitas inovasi memiliki asosiasi yang kuat dengan keberhasilan industri dalam menopang kinerja dan pertumbuhan usahanya (Abereijo, 2007; Shan dan Jolly, 2010). Aktivitas inovasi merupakan kunci penting untuk memenangkan persaingan industri dewasa ini (Karagouni dan Papadopoulos, 2007). Selain itu, inovasi teknologi tidak dapat dihindari jika perusahaan ingin mengembangkan dan mempertahankan keunggulan kompetitifnya serta menembus pasar baru (Becheikh dkk., 2006). Melalui inovasi teknologi, perusahaan dapat memilih, menerapkan dan menggunakan teknologi secara efisien dibandingkan dengan pesaing (Azubuike, 2013).

Sejauh ini, studi terkait kapabilitas teknologi inovasi (technological innovation capability) atau lebih sering disingkat dengan TIC, memberikan kerangka keseluruhan untuk memahami pentingnya kapabilitas tersebut sebagai sumber daya untuk meningkatkan keunggulan kompetitif (Lang dkk., 2012). Walaupun sudah ada beberapa penelitian tentang TIC di Indonesia, mayoritas penelitian tersebut dilakukan pada usaha kecil menengah (Lianto dkk., 2015; Rianto, 2006; Rinawiyanti dan Lianto, 2016; Rinawiyanti dkk., 2018; Siyamtinah dkk., 2011).

Nilai dan jumlah produksi industri alas kaki nasional sebagian besar dihasilkan oleh industri menengah dan besar (Kemenperin, 2018). Perusahaan yang lebih besar dikatakan lebih inovatif dibandingkan dengan perusahaan yang lebih kecil (Baldwin, 1999). Sampai saat ini, studi terkait TIC pada industri alas kaki lebih banyak difokuskan pada UKM (Lianto dkk., 2015; Rinawiyanti dan Lianto, 2016; Rinawiyanti dkk., 2018). Sehingga, perlu dilakukan penilaian sejauh mana industri alas kaki menengah dan besar melakukan TIC.

Berdasarkan alasan tersebut, studi ini dilakukan dengan tujuan untuk (i) menginvestigasi TIC pada industri alas kaki menengah dan besar di Jawa Timur dan (ii) 
menganalisa apakah terdapat perbedaan TIC yang dipengaruhi oleh karakteristik perusahaan. Temuan dari studi ini diharapkan dapat memberikan deskripsi mengenai TIC industri alas kaki, di Jawa Timur khususnya, sehingga dapat diketahui dimensi TIC mana yang perlu diperbaiki untuk meningkatkan keunggulan kompetitif.

\section{Landasan Teori}

Inovasi merupakan salah satu dimensi terpenting pada industri manufaktur (Theodorou dan Florou, 2008) dan sebagai salah satu pendorong utama dalam orientasi strategis sebuah perusahaan (Paraschiv dkk., 2012). Inovasi dipertimbangkan sebagai penggerak perubahan karena organisasi yang menyadari inovasi baru dan cepat mengadopsinya dapat menciptakan keunggulan kompetitif bagi organisasi tersebut dengan mengubah apa yang mereka lakukan dan bagaimana mereka melakukannya (Smit, 2015). Studi pada UKM alas kaki di Mojokerto menyoroti bahwa inovasi memiliki pengaruh positif dan signifikan terhadap kinerja usaha. Semakin tinggi inovasi maka semakin tinggi kinerja usaha (Inayati, 2018).

Kapabilitas inovasi merupakan salah satu faktor penting untuk mengembangkan inovasi dalam perusahaan. Kapabilitas inovasi memberikan wawasan tentang potensi dan aset inovasi perusahaan, yang mengarah pada identifikasi titik terkuat dan terlemah, di mana perusahaan dapat bertumbuh (Rajapathirana and Hui, 2018).

Inovasi teknologi adalah keterampilan yang terlibat untuk mewujudkan dan mendukung strategi inovasi teknologi perusahaan (Yam dkk., 2004). Inovasi teknologi merupakan proses yang melibatkan interaksi dari berbagai sumber daya (Guan dan Ma, 2003). Melalui kombinasi dari teknik pengetahuan dan keterampilan manajemen dari berbagai bidang dan dengan memperkuat bidang-bidang tersebut, perusahaan dapat membangun keunggulan kompetitifnya (Guan dkk., 2006).

Kapabilitas inovasi teknologi (TIC) didefinisikan sebagai serangkaian karakteristik perusahaan atau organisasi yang komprehensif untuk memfasilitasi dan mendukung strategi inovasi teknologi organisasi tersebut (Burgelman dkk., 2004). TIC meliputi berbagai aset dan sumber daya khusus perusahaan dalam melakukan aktivitas inovasi, yang terdiri dari teknologi, produk, proses, pengetahuan, pengalaman dan organisasi (Guan dan Ma, 2003).

TIC dapat diungkapkan melalui tujuh dimensi sebagai berikut: (Guan dan Ma, 2003; Yam dkk., 2004; Yam dkk., 2011)

1. Kapabilitas belajar (learning capability): kemampuan perusahaan untuk mengidentifikasi, mengasimilasi dan memanfaatkan pengetahuan dari lingkungannya.

2. Kapabilitas $\mathrm{R} \& \mathrm{D}(R \& D$ capability): kemampuan perusahaan untuk mengintegrasikan strategi kegiatan penelitian dan pengembangan, pelaksanaan proyek, manajemen portofolio proyek, dan tingkat pengeluaran untuk kegiatan penelitian dan pengembangan.

3. Kapabilitas alokasi sumber daya (resources allocation capability): kemampuan perusahaan untuk menyediakan modal yang memadai, tenaga profesional dan investasi teknologi dalam proses inovasi.

4. Kapabilitas manufakturing (manufacturing capability): kemampuan perusahaan untuk mentransformasikan hasil penelitian dan kegiatan pengembangannya menjadi produk yang memenuhi kebutuhan pasar.

5. Kapabilitas pemasaran (marketing capability): kemampuan perusahaan untuk mempublikasikan dan memasarkan produknya berdasarkan pada pemahaman yang baik tentang kebutuhan konsumen, kondisi persaingan, analisis biaya dan manfaat, dan penerimaan hasil inovasi. 
6. Kapabilitas organisasi (organizational capability): kemampuan perusahaan untuk menjalankan mekanisme organisasi yang baik dan memperkuat budaya organisasi, serta kemampuan mengadopsi praktik manajemen organisasi yang sehat dan profesional.

7. Kapabilitas perencanaan strategi (strategy planning capability): kemampuan perusahaan untuk menentukan dan menganalisis kekuatan dan kelemahan internal, serta peluang dan tantangan eksternal yang dihadapi, kemampuan merumuskan rencana kerja yang sesuai dengan visi dan misi perusahaan serta mengimplementasikan seluruh rencana kerja dengan baik.

TIC mengubah kesulitan multi-dimensi yang melibatkan banyak fungsi organisasi dan integrasi di antara berbagai faktor untuk meningkatkan peluang kompetitif perusahaan. TIC telah menjadi salah satu bidang studi yang paling menarik dan menjanjikan di bidang manajemen inovasi teknologi (Lang dkk., 2012). Beberapa studi memberikan bukti empiris bahwa TIC dapat meningkatkan kinerja perusahaan dan keunggulan kompetitif perusahaan (Chen dkk., 2020; Karagouni dan Papadopoulos, 2007; Lang dkk., 2012; Lianto dkk., 2015; Yousefi dkk., 2013; Siyamtinah dkk., 2011; Yam dkk., 2004).

Kapabilitas perusahaan untuk berinovasi bervariasi sesuai dengan sektor bisnis, skala, fokus, sumber daya dan lingkungan bisnis dimana perusahaan beroperasi (Burroine dan Jaya, disitasi pada Rinawiyanti dan Lianto, 2016). Terkait dengan skala (ukuran), perusahaan yang lebih besar dikatakan lebih inovatif dibandingkan dengan perusahaan yang lebih kecil, antara lain karena perusahaan besar memiliki lebih banyak kemudahan pada akses pembiayaan, dapat membagikan biaya tetap inovasi pada volume penjualan yang lebih besar, manfaat yang diperoleh dari economies of scale, dan saling melengkapinya (complementarities) antara riset dan pengembangan dengan aktivitas-aktivitas perusahaan yang lain (Baldwin, 1999). Usia perusahaan mencerminkan periode keberadaan operasional perusahaan, yaitu berapa tahun perusahaan telah beroperasi sejak didirikan (Deakin dan Massey, disitasi pada Moohammad dkk., 2014). Skala dan usia perusahaan dapat digunakan sebagai faktor kontrol dalam pengukuran inovasi perusahaan (Moohammad dkk., 2014) dan merupakan faktor penting yang perlu diperhatikan dalam proses pengembangan kapabilitas inovasi (Rinawiyanti dan Lianto, 2016).

\section{Metode Penelitian}

Studi ini menggunakan metode kuantitatif untuk mengumpulkan, menganalisis, dan mengintegrasikan data penelitian untuk menemukan jawaban atas pertanyaan penelitian (Johnson dan Onwuegbuzie, 2004) karena bisa memberikan informasi tentang banyak karakteristik (Hair dkk., 2011). Selain merupakan metode penilaian ilmu sosial dan perilaku yang sangat efektif, survei juga fleksibel mengingat banyaknya instrumen dan pilihan pengumpulan data yang tersedia (Ruel dkk., 2016). Sebuah survei menghasilkan deskripsi kuantitatif tentang pola, perilaku, atau pendapat suatu populasi dengan mempelajari sampel dari populasi itu (Creswell, 2014). Dengan pertimbangan tersebut, studi ini melakukan survei dengan menggunakan kuesioner untuk mendapatkan data (Creswell, 2014) dengan mengumpulkan sikap dan pendapat individu tentang fenomena yang menarik untuk memperoleh bukti empiris (Bryman, 2011). Dengan demikian, studi ini menggunakan pengukuran subyektif berdasarkan persepsi responden melalui kuesioner (Kim dkk., 2004).

Kuesioner yang digunakan pada studi ini terdiri dari dua bagian. Bagian pertama berisi lima pertanyaan tentang karakteristik responden, seperti jumlah karyawan, usia perusahaan, sistem produksi, jenis produk dan orientasi pasar. Bagian kedua terdiri dari 33 pertanyaan dengan tujuh dimensi TIC diadopsi dari Yam dkk. (2010), setelah disesuaikan dengan situasi dan kondisi industri alas kaki Jawa Timur berdasarkan hasil survei awal. 
Bagian kedua berisi 4 variabel untuk learning capability, 3 variabel untuk $R \& D$ capability, 5 variabel untuk resource allocation capability, 7 variabel untuk manufacturing capability, 5 variabel untuk marketing capability, 6 variabel untuk organizational capability dan 3 variabel untuk strategy planning capability. Studi ini menggunakan pendekatan fungsional untuk dimensi TIC karena mempunyai beberapa keunggulan, antara lain mudah untuk dimengerti dan telah banyak digunakan dalam beberapa studi saat ini (Yam dkk., 2011).

Semua pertanyaan dalam kuesioner merupakan pertanyaan tertutup. Beberapa pilihan jawaban disediakan untuk setiap pertanyaan, sehingga responden cukup melingkari jawaban yang sesuai (Fowler, 2014). Pada bagian pertama, disediakan pilihan ganda dan responden memilih satu jawaban yang paling sesuai dengan karakteristik perusahaannya. Di bagian kedua, responden memilih skala yang menggambarkan penerapan TIC di perusahaannya dari $1=$ sangat tidak setuju sampai $5=$ sangat setuju. Skor yang lebih tinggi menunjukkan kekuatan yang lebih besar pada dimensi TIC yang terkait.

Sampel pada studi ini adalah 62 industri alas kaki menengah dan besar di Jawa Timur yang tergabung dalam Asosiasi Persepatuan Indonesia (APRISINDO). Organisasi ini didirikan pada tahun 1988 dengan tujuan untuk mempertahankan eksistensi industri alas kaki yang terus berkembang dan meningkatkan kemampuannya untuk bersaing di pasar global (APRISINDO, 2019). Dengan demikian, studi ini menggunakan perusahaan sebagai unit analisa. Ukuran perusahaan diukur berdasarkan jumlah karyawan (Effendi dan Kusmantini, 2015; Swink dkk., 2005), mengikuti kategori dari Badan Pusat Statistik Indonesia, yaitu kecil (5-19 karyawan), menengah (20-99 karyawan) dan besar (lebih dari 100 karyawan).

Sebelum kuesioner dibagikan, studi ini melakukan survei awal pada tiga industri alas kaki di Sidoarjo (salah satu kabupaten yang merupakan sentra industri alas kaki di Jawa Timur). Berdasarkan hasil dari survei awal, dilakukan perubahan pada beberapa pertanyaan kuisioner, supaya pertanyaan lebih mudah dipahami dan sesuai dengan situasi dan kondisi industri alas kaki. Kuesioner yang sudah diperbaiki kemudian dikirimkan kepada responden, yaitu direktur dan manajer senior (antara lain manajer pabrik, manajer produksi dan manajer PPIC). Karena mempunyai pemahaman yang komprehensif tentang strategi dan kegiatan perusahaan terkait dengan TIC, mereka dipertimbangkan sebagai informan yang tepat untuk meminimalkan bias (Huber dan Power, 1985; Miller dan Roth, 1994) dan mampu untuk melengkapi jawaban dalam kuesioner. Dari 62 responden yang mendapat kuesioner, 30 responden (48.38\%) mengisi dan mengembalikan kuesioner. Selanjutnya data dianalisa dengan menggunakan SPSS, baik untuk menghitung nilai rata-rata variabel dan tiap dimensi TIC untuk menilai implementasi TIC, maupun uji MANOVA dan uji crosstab untuk mengetahui perbedaan TIC berdasarkan karakteristik perusahaan.

\section{Hasil dan Pembahasan}

Sebelum dianalisa, terlebih dahulu dilakukan pengujian validitas dan reliabilitas data. Validitas menentukan apakah suatu instrumen mengukur apa yang dimaksudkan untuk diukur, sedangkan reliabilitas berarti kuesioner merepresentasikan konstruk yang dinilai secara konsisten (Field, 2009). Reliabilitas mengukur sejauh mana pengukuran bebas dari kesalahan acak, dan dengan demikian menghasilkan hasil yang dapat diandalkan (Venkatraman, 1989).

Uji validitas dilakukan dengan mengukur nilai Corrected Item-Total Correlation, yang dapat dikatakan valid apabila $R_{\text {hitung }}>R_{\text {tabel. }}$ Sedangkan uji reliabilitas ditentukan oleh nilai Croncbach's alpha, yang berarti reliabel bila nilainya lebih besar dari 0,70 (Pallant, 2005). Hasil SPSS menunjukkan bahwa semua variabel dimensi TIC valid dengan nilai Cronbach's alpha di atas 0,70 dan reliabel dengan nilai corrected item-total correlation lebih 
besar dari $\mathrm{R}_{\text {tabel }}(0,361, \mathrm{df}=28)$. Dengan demikian, data valid dan reliabel, sehingga dapat digunakan untuk analisa lebih lanjut.

\section{Profil Responden}

Tabel 1 menampilkan profil responden. Berdasarkan ukuran perusahaan, dapat dilihat bahwa sebagian besar perusahaan responden (40\%) mempunyai lebih dari 700 karyawan, 26,7\% memiliki 501-700 karyawan dan 16,7\% mempunyai kurang dari 100 karyawan. Selebihnya (16,6\%) memiliki 100-500 karyawan.

Hampir separuh perusahaan responden (43\%) telah beroperasi diatas 20 tahun, sedangkan 23\% mempunyai masa operasi kurang dari 5 tahun dan $17 \%$ beroperasi antara 16 sampai 20 tahun. Dari data di Tabel 1 dapat dilihat bahwa sistem produksi yang banyak dijalankan oleh perusahaan responden adalah gabungan (job order dan make to stock) dengan prosentase sebesar 53\%, diikuti oleh sistem produksi job order (pesanan) (40\%). Sistem produksi yang paling jarang diterapkan yaitu sistem produksi make to stock (7\%). Mayoritas perusahaan responden (70\%) menghasilkan produk sandal dan sepatu dan $27 \%$ hanya membuat sepatu. Selebihnya (3\%) hanya membuat sandal.

Lebih dari separuh perusahaan responden $(56,7 \%)$ mempunyai orientasi pasar gabungan antara domestik dan ekspor. Sedangkan 23,3\% memiliki orientasi pasar domestik saja dan selebihnya (20\%) berorientasi pasar ekspor. Terkait dengan kepemilikan, perusahaan responden didominasi dengan penanaman modal dalam negeri (94\%), sedangkan sisanya (3\%) mempunyai penanaman modal asing dan gabungan. Mengenai jumlah model produk, sebagian besar perusahaan responden $(63,3 \%)$ telah menghasilkan lebih dari 30 macam produk dan $16,7 \%$ memproduksi 10-20 macam produk. Selebihnya $(13,3 \%)$ mempunyai kurang dari 10 macam produk.

Table 1. Profil Responden

\begin{tabular}{|c|c|c|c|c|}
\hline No & Variabel & Jawaban & Frekuensi & Prosentase (\%) \\
\hline \multirow[t]{5}{*}{1.} & Jumlah karyawan & $<100$ & 5 & 16,7 \\
\hline & & $101-300$ & 1 & 3,3 \\
\hline & & $301-500$ & 4 & 13,3 \\
\hline & & $501-700$ & 8 & 26,7 \\
\hline & & $>700$ orang & 12 & 40 \\
\hline \multirow[t]{5}{*}{2.} & Usia perusahaan & $<5$ & 7 & 23 \\
\hline & (tahun) & $6-10$ & 2 & 7 \\
\hline & & $11-15$ & 3 & 10 \\
\hline & & $16-20$ & 5 & 17 \\
\hline & & $>20$ & 13 & 43 \\
\hline \multirow[t]{3}{*}{3.} & Sistem produksi & Job order & 12 & 40 \\
\hline & & Make to stock & 2 & 7 \\
\hline & & Kombinasi & 16 & 53 \\
\hline \multirow[t]{3}{*}{4.} & Jenis produk & Sandal & 1 & 3 \\
\hline & & Sepatu & 8 & 27 \\
\hline & & Sandal dan sepatu & 21 & 70 \\
\hline \multirow[t]{3}{*}{5.} & Orientasi pasar & Domestik & 7 & 23,3 \\
\hline & & Ekspor & 6 & 20 \\
\hline & & Kombinasi & 17 & 56,7 \\
\hline \multirow[t]{3}{*}{6.} & Kepemilikan modal & PMDN & 28 & 94 \\
\hline & & PMA & 1 & 3 \\
\hline & & Gabungan & 1 & 3 \\
\hline \multirow[t]{3}{*}{7.} & Banyaknya tipe produk & $10-20$ macam & 5 & 16,7 \\
\hline & yang dihasilkan & 20-30 macam & 2 & 6,7 \\
\hline & perusahaan & $>30$ macam & 19 & 63,3 \\
\hline
\end{tabular}




\section{Statistik Deskriptif}

Statistik deskriptif digunakan untuk memberikan informasi deskriptif tentang variabel yang diukur, meliputi variabel dependen dan variabel independen, seperti nilai rata-rata (mean) sebagai model statistik dari data (Field, 2009). Penilaian TIC pada industri menengah dan besar di Jawa Timur dilakukan dengan menghitung nilai rata-rata tiap variabel (mean) dan tiap dimensi (grand mean). Kemudian, nilai tersebut dikategorikan rendah, sedang dan tinggi dengan perhitungan interval skala sebagai berikut:

Interval $=\frac{(\mathrm{N}-1)}{\mathrm{n}}=\frac{(5-1)}{3}=\frac{4}{3}=1,33$

Dengan skala 1 sampai 5, maka interval 1,00-2,33 adalah kategori rendah, 2,34-3,67 merupakan kategori sedang, sedangkan 3,68-5 termasuk kategori tinggi.

Tabel 2 menampilkan hasil perhitungan nilai rata-rata variabel dan dimensi TIC dengan penjelasan sebagai berikut:

1. Dimensi learning capability tergolong dalam kategori sedang dengan nilai rata-rata 3,51. Hal ini terjadi karena keempat variabel dimensi ini mendapatkan nilai rata-rata di kategori sedang. Dapat disimpulkan bahwa pada industri alas kaki menengah besar di Jawa Timur variabel keterampilan karyawan, pelatihan dan pengembangan karyawan dan diskusi/sharing merupakan hal yang diperhatikan dengan nilai rata-rata 3,56, 3,53 dan 3,63. Sedangkan pendidikan karyawan (nilai rata-rata 3,30) merupakan hal yang tidak begitu diperhatikan dalam perekrutan karyawan di industri alas kaki di Jawa Timur.

2. Dimensi $R \& D$ capability mendapatkan nilai rata-rata pada kategori tinggi $(3,72)$. Dapat dikatakan bahwa bagian $R \& D$ memiliki peran yang penting pada industri alas kaki menengah dan besar di Jawa Timur, karena variabel "Adanya bagian $R \& D$ secara formal" dan "Kontribusi $R \& D$ pada kinerja perusahaan" berada pada kategori tinggi dengan nilai rata-rata 3,76 dan 3,73. Secara keseluruhan dapat dikatakan bahwa industri alas kaki menengah dan besar di Jawa Timur mempunyai kapabilitas $R \& D$ yang memadai.

3. Dimensi resource allocation capability memperoleh nilai rata-rata 3,42, kategori sedang. Sebagian besar variabel pada dimensi ini mendapatkan nilai rata-rata di kategori sedang, yaitu "Kemudahan mendapatkan bahan baku" $(3,4)$, "Ketersediaan modal" $(3,46)$ dan "Kemudahan mendapatkan karyawan" $(3,00)$. Dengan kata lain, industri alas kaki menengah dan besar di Jawa Timur mempunyai kesulitan untuk mendapatkan bahan baku, modal usaha dan karyawan.

4. Dimensi manufacturing capability mendapatkan nilai rata-rata di kategori tinggi, yaitu 3,94. Hampir semua variabel pada dimensi ini mendapatkan nilai rata-rata yang tinggi, antara lain "Pemenuhan order" $(4,03)$, "Kualitas produk" $(4,4)$ dan "Standarisasi produk" $(4,2)$. Hasil tersebut memberikan indikasi bahwa secara keseluruhan kapabilitas manufaktur industri alas kaki menengah dan besar di Jawa Timur telah berjalan dengan baik, yang mencerminkan perusahaan dapat memenuhi semua order dengan baik, menghasilkan produk dengan kualitas yang baik dan mengikuti standarisasi produk. Hanya ada satu variabel dengan nilai rata-rata sedang, yaitu "Pengaturan lantai produksi" $(3,56)$, yang menyatakan bahwa pengaturan lantai produksi pada industri alas kaki menengah dan besar di Jawa Timur belum efektif dan efisien.

5. Dimensi marketing capability termasuk dalam kategori sedang dengan nilai rata-rata 3,44. Ada beberapa variabel yang memiliki nilai rata-rata di kategori sedang, yaitu "Merek produk sendiri" $(3,53)$, "Pemasaran produk secara online" $(2,66)$, "Adanya tim marketing" 
$(3,56)$ dan "Jalur distribusi" $(3,63)$. Secara umum, hasil ini menyatakan bahwa industri alas kaki menengah dan besar di Jawa Timur belum sepenuhnya memiliki kapabilitas pemasaran yang memadai karena tidak semua perusahaan memiliki merek produk sendiri dan memasarkan produk mereka melalui media online. Selain itu, masih ada perusahaan yang belum memiliki bagian marketing untuk memasarkan produk mereka dan masih ada perusahaan yang kesulitan mendistribusikan produk mereka. Sedangkan variabel "Pasar perusahaan" mendapatkan nilai rata-rata tinggi $(3,86)$, yang artinya pasar untuk industri alas kaki di Jawa Timur mempunyai prospek yang cerah dan permintaan yang ada masih cukup besar.

6. Dimensi organizational capability dikategorikan tinggi dengan nilai rata-rata 3,85. Semua variabel yang termasuk dalam konstruk organization capability memiliki nilai rata-rata di kategori tinggi, antara lain "Hubungan pimpinan dan karyawan" (4,1), "Proses kepemimpinan" (3,93), "Struktur organisasi" $(3,83)$. Secara keseluruhan kapabilitas organisasi pada industri alas kaki di Jawa Timur dikatakan sangat baik. Hampir semua perusahaan mempunyai hubungan yang baik antara pimpinan dan karyawan, menjalankan proses kepemimpinan yang baik dan telah memiliki struktur organisasi yang baik dan jelas.

7. Dimensi strategic planning capability termasuk dalam kategori tinggi dengan nilai ratarata 3,73. Dua variabel mendapatkan nilai rata-rata tinggi, yaitu "Strategi pengembangan usaha" $(3,7)$ dan "Kerja sama dengan pihak lain" $(3,9)$. Sedangkan variabel "Strategi menghadapi pesaing" memperoleh nilai rata-rata 3,6, kategori sedang. Dengan demikian secara keseluruhan industri alas kaki di Jawa Timur mempunyai kapabilitas perencanaan strategi yang baik karena mempunyai strategi pengembangan usaha yang terencana dan hubungan dengan pihak lain baik, walaupun masih ada perusahaan yang belum memiliki strategi menghadapi pesaing yang efektif.

Tabel 2. Nilai Rata-rata Variabel dan Dimensi TIC

\begin{tabular}{|c|c|c|c|c|c|}
\hline Variabel & Mean & $\begin{array}{l}\text { Grand } \\
\text { mean }\end{array}$ & Variabel & Mean & $\begin{array}{l}\text { Grand } \\
\text { mean }\end{array}$ \\
\hline Learning capability & & 3,51 & Strategic planning capability & & 3,73 \\
\hline Pendidikan karyawan & 3,30 & & Strategi pengembangan usaha & 3,70 & \\
\hline Keterampilan karyawan & 3,56 & & Strategi menghadapai pesaing & 3,60 & \\
\hline Pelatihan dan pengembangan karyawan & 3,53 & & Kerja sama dengan pihak lain & 3,90 & \\
\hline Diskusi/sharing antar karyawan & 3,63 & & Organization capability & & 3,85 \\
\hline Resources allocation capability & & 3,42 & Struktur organisasi & 3,83 & \\
\hline Kemudahan memperoleh bahan baku & 3,40 & & $\begin{array}{l}\text { Standar operasional prosedur } \\
\text { (SOP) }\end{array}$ & 3,76 & \\
\hline Ketersediaan modal & 3,46 & & Proses kepemimpinan & 3,93 & \\
\hline Kemudahan mendapatkan karyawan & 3,00 & & Budaya perusahaan & 3,73 & \\
\hline Jumlah karyawan saat ini & 3,40 & & Aturan kerja karyawan & 3,80 & \\
\hline $\begin{array}{l}\text { Lokasi perusahaan mendukung kegiatan } \\
\text { operasional perusahaan }\end{array}$ & 3,83 & & $\begin{array}{l}\text { Hubungan pimpinan dan } \\
\text { karyawan }\end{array}$ & 4,10 & \\
\hline$R \& D$ capability & & 3,72 & Manufacturing capability & & 3,94 \\
\hline Adanya bagian R \& D secara formal & 3,76 & & Peralatan kerja & 3,96 & \\
\hline Kegiatan riset dan pengembangan $(\mathrm{R} \& \mathrm{D})$ & 3,66 & & Mesin produksi modern & 3,73 & \\
\hline Kontribusi R \& D pada kinerja perusahaan & 3,73 & & Pemenuhan order & 4,03 & \\
\hline Marketing capability & & 3,44 & Pengaturan lantai produksi & 3,56 & \\
\hline Pasar perusahaan & 3,86 & & Kualitas produk & 4,40 & \\
\hline Ada merek produk sendiri & 3,53 & & Standarisasi produk & 4,20 & \\
\hline Pemasaran produk secara online & 2,66 & & Sistem perawatan mesin dan & 3,70 & \\
\hline Adanya tim marketing & 3,56 & & peralatan & & \\
\hline Jalur distribusi & 3,63 & & & & \\
\hline
\end{tabular}


Gambar 1 mencerminkan hasil rekapitulasi rata-rata TIC. Secara keseluruhan tujuh dimensi TIC mendapatkan nilai rata-rata antara 3,22 sampai 3,94. Jika diurutkan, maka dimensi yang mendapatkan nilai rata-rata tertinggi adalah manufacturing capability $(3,94)$, organization capability $(3,85)$, diikuti oleh strategic planning capability $(3,73)$ dan $R \& D$ capability $(3,72)$, kemudian learning capability $(3,51)$, marketing capability $(3,44)$ dan yang terakhir resource allocation capability $(3,42)$. Hasil tersebut menggambarkan bahwa TIC industri alas kaki menengah dan besar di Jawa Timur di kategori sedang dan tinggi. Mereka mempunyai TIC yang tinggi di empat dimensi, yaitu manufacturing capability, organization capability, strategic planning capability dan $R \& D$ capability. Tetapi untuk tiga dimensi yang lain, mereka masih mempunyai TIC di kategori sedang, yaitu learning capability, marketing capability dan resource allocation capability.

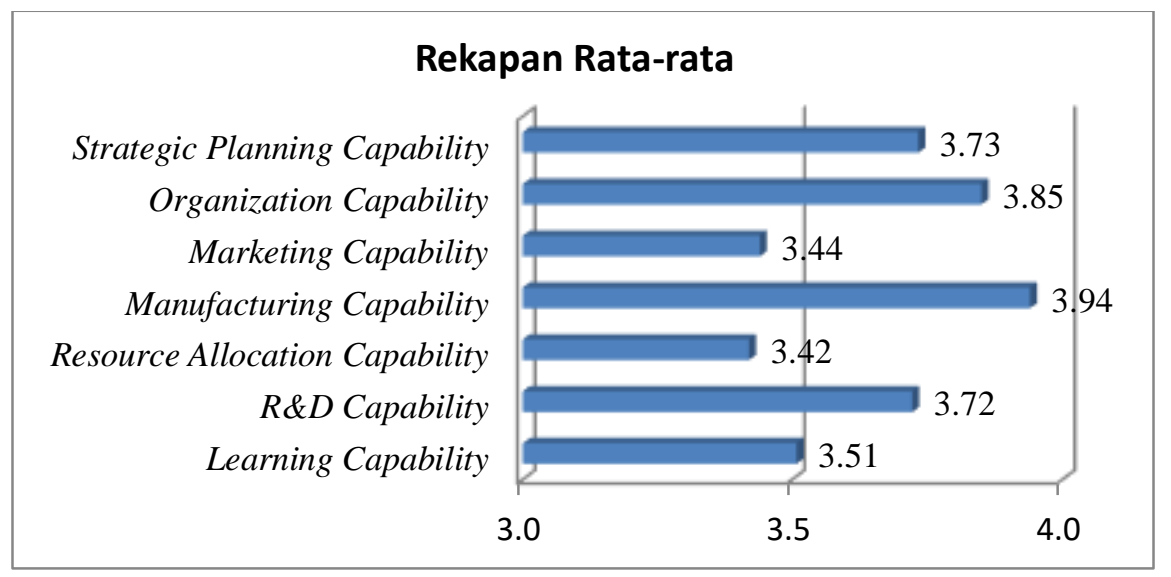

Gambar 1. Rekapitulasi Nilai Rata-rata Dimensi TIC

Temuan ini mempunyai kemiripan dengan hasil studi TIC pada UKM alas kaki di Sidoarjo dan Surabaya, di mana manufacturing capability dan strategic planning capability mendapatkan nilai rata-rata tinggi, sedangkan resource capability dan marketing capability memperoleh nilai rata-rata yang sedang (Rinawiyanti dan Lianto, 2016; Rinawiyanti dkk., 2018). Tetapi, temuan studi ini sedikit berbeda dengan hasil studi TIC pada UKM alas kaki di Mojokerto, yang menunjukkan bahwa seluruh dimensi TIC mendapatkan nilai rata-rata yang tinggi (Lianto dkk., 2015).

Tabel 2 menampilkan tiga variabel dengan nilai rata-rata tertinggi, yaitu "Kualitas produk" $(4,4)$, "Standarisasi produk" $(4,2)$ dan "Hubungan pimpinan dan karyawan" $(4,1)$. Sedangkan tiga variabel dengan nilai rata-rata terendah yaitu: "Pemasaran produk secara online" (2,66), "Kemudahan mendapatkan karyawan" (3) dan "Pendidikan karyawan" $(3,3)$. Temuan ini mencerminkan bahwa industri alas kaki menengah dan besar di Jawa Timur memperhatikan kualitas produk, menerapkan standarisasi produk dan menjaga hubungan pimpinan dan karyawan. Tetapi, mereka belum mengimplementasikan pemasaran produk secara online serta menghadapi kesulitan untuk mendapatkan karyawan dengan pendidikan yang memadai.

Dari hasil pengukuran TIC, beberapa saran perbaikan bisa dilakukan pada beberapa variabel yang mendapatkan nilai rata-rata di kategori sedang sebagai berikut:

1. Dimensi learning capability. Meskipun pendidikan karyawan memiliki nilai rata-rata rendah $(3,30)$, perusahaan lebih mementingkan keterampilan karyawan $(3,56)$, sehingga variabel inilah yang harus diperbaiki, yang dapat dilakukan melalui pelatihan dan pengembangan karyawan $(3,53)$. Karena pelatihan dan pengembangan karyawan pada 
industri alas kaki di Jawa Timur masih tergolong sedang atau masih jarang dilakukan maka perlu ditingkatkan dengan membuat perencanaan pelatihan dan pengembangan karyawan sehingga terencana dengan baik dan dapat dilaksanakan secara teratur. Tidak hanya itu, peningkatan learning capability juga dapat dilakukan dengan lebih sering mengadakan diskusi/sharing antar karyawan sehingga semua karyawan memahami permasalahan ataupun metode baru yang ada di perusahaan. Diskusi antar karyawan berarti bahwa perusahaan memberdayakan karyawan dengan menghargai pendapat mereka dan meningkatkan kerja sama di antara karyawan. Karena pemberdayaan memberikan pengaruh yang positif dan signifikan pada produktivitas (Pramayani dan Adnyani, 2018), maka diharapkan dimensi learning capability mengalami peningkatan melalui kegiatan tersebut.

2. Dimensi marketing capability. Variabel "Pemasaran produk secara online" mendapatkan nilai rata-rata terendah $(2,66)$. Tindakan perbaikan yang dapat dilakukan adalah dengan memberikan pelatihan pembuatan website perusahaan. Melalui pelatihan tersebut diharapkan karyawan mampu dan terampil untuk mendesain dan membuat website yang dapat menampilkan informasi perusahaan dan produk dengan baik.

3. Dimensi resource allocation capability. Variabel yang memiliki nilai rata-rata terendah ialah "Kemudahan mendapatkan karyawan" $(3,00)$. Masalah yang sering dihadapi yaitu banyak karyawan yang tidak bekerja waktu permintaan banyak, misalnya menjelang hari raya atau masuk sekolah. Untuk mengatasi masalah ini, perusahaan dapat menerapkan aturan kerja yang jelas dan tegas. Misalnya, karyawan harus memberitahukan bila tidak masuk kerja dengan alasan yang penting dan mendesak. Bila tidak, maka perusahan bisa memberikan sanksi pengurangan gaji atau denda. Dengan demikian, para karyawan akan lebih tertib dan disiplin, serta lebih termotivasi untuk bekerja. Karena motivasi karyawan berpengaruh positif pada produktivitas kerjanya (Pramayani dan Adnyani, 2018), maka diharapkan karyawan yang termotivasi akan bekerja dengan baik, disiplin dan jarang bolos, sehingga produktivitas kerja meningkat.

Selain perbaikan yang bisa dikerjakan oleh perusahaan, pemerintah telah melakukan berbagai upaya untuk meningkatkan TIC industri alas kaki di Jawa Timur, antara lain:

1. Pemerintah mendirikan Balai Pengembangan Industri Persepatuan Indonesia (BPIPI), yang berlokasi di Sidoarjo, Jawa Timur. BPIPI memiliki tugas dalam pembinaan dan pengembangan industri alas kaki di Indonesia. Fokus pelayanan BPIPI antara lain peningkatan SDM industri alas kaki, peningkatan pengetahuan dan teknologi produk alas kaki, serta standardisasi produk alas kaki (Wardani, 2019). Diharapkan layanan tersebut dapat meningkatkan TIC pada dimensi learning capability dan manufacturing capability.

2. Untuk meningkatkan ketrampilan karyawan, Badan Pengembangan Sumber Daya Manusia Industri (BPSDMI) rutin mengadakan Diklat 3inl (pelatihan, sertifikasi, dan penempatan kerja) untuk operator jahit upper alas kaki. Pelaksanaannya tersebar di tujuh Balai Diklat Industri Kementerian Perindustrian yang bekerjasama dengan pusat pelatihan milik perusahaan atau asosiasi industri. Selama diklat, peserta dibekali dengan pengetahuan, keterampilan dan sikap kerja yang dibutuhkan dalam mengoperasikan mesin jahit upper alas kaki oleh tenaga instruktur yang mayoritas berasal dari pihak industri dan asosiasi. Pada akhir pelatihan, peserta mengikuti sertifikasi kompetensi dengan mekanisme uji kompetensi oleh Lembaga Sertifikasi Profesi yang ditunjuk dengan skema sesuai materi pelatihan yang diberikan. Dengan demikian, peserta akan mendapat pengakuan terhadap kompetensi yang dimilikinya sehingga mampu meningkatkan produktivitas kerja 
dan daya saing industri (Pratiwi, 2020). Jika karyawan lebih terampil, maka TIC pada dimensi learning capability juga akan meningkat.

3. Baru-baru ini, Kementerian Perindustrian menginisiasi pembentukan Indonesia Footwear Network (IFN) sebagai sebuah platform jejaring bagi pelaku industri alas kaki dan pendukungnya. Platform IFN merupakan sebuah etalase yang menampilkan informasi pelaku bisnis usaha yang terdiri dari produk, pemasok, dan produsen sehingga dapat diakses oleh seluruh pelaku usaha bidang alas kaki dan produk kulit. Platform IFN memberikan kesempatan bagi industri alas kaki untuk membangun jaringan antar pebisnis, menciptakan peluang kerja sama dan meningkatkan citra diri personal hingga branding perusahaan (Ramadhani, 2020). Usaha ini bisa membantu perusahaan untuk melakukan pemasaran online, yang dapat meningkatkan TIC pada dimensi marketing capability. Selain itu, platform IFN dapat dipertimbangkan sebagai strategi untuk menghadapi pesaing, karena penggunaan informasi dan teknologi tidak bisa dihindari lagi di era revolusi industri 4.0 jika perusahaan ingin berkompetisi secara global. Sehingga, kegiatan ini diharapkan dapat meningkatkan TIC pada dimensi strategic planning capability.

\section{Uji Multivariate Analysis of Variance (MANOVA) pada TIC}

Setelah menilai tiap dimensi TIC, selanjutnya dilakukan pengujian analisis varians multivariasi (MANOVA) untuk membandingkan TIC pada sejumlah variabel dependen yang berbeda namun terkait (Pallant, 2005). Ada empat karakteristik perusahaan yang dinilai, yaitu jumlah karyawan, usia perusahaan, sistem produksi dan orientasi pasar. Pada uji MANOVA, hipotesis yang akan diuji yaitu:

$\mathrm{H}_{0}$ : Tidak terdapat perbedaan TIC terhadap karakteristik perusahaan.

$\mathrm{H}_{1}$ : Terdapat perbedaan TIC terhadap karakteristik perusahaan.

Dari empat statistik yang dihasilkan oleh uji MANOVA, studi ini menggunakan Wilks' lambda, sebagai statistik yang paling banyak digunakan dan direkomendasikan untuk penggunaan umum (Pallant, 2005). Pengolahan data menggunakan tingkat signifikasi 5\% dan $\mathrm{H}_{0}$ ditolak jika nilai signifikansi Wilks' lambda $<0,05$, yang menandakan ada perbedaan di antara grup yang diuji (Field, 2009; Pallant, 2005).

Tabel 3 menampilkan hasil pengujian MANOVA secara keseluruhan. Untuk jumlah karyawan, nilai signifikansi Wilks' lambda 0,291 (>0,05). Hal ini menunjukkan bahwa tidak terdapat perbedaan TIC yang signifikan terhadap jumlah karyawan. Dengan kata lain, TIC perusahaan besar sama dengan TIC perusahaan menengah.

Terkait usia perusahaan, uji MANOVA mendapatkan nilai signifikansi Wilks' lambda $0,016(<0,05)$. Hasil ini mengindikasikan perbedaan kapabilitas inovasi terhadap usia perusahaan. Dapat dikatakan bahwa usia perusahaan berpengaruh terhadap TIC karena perusahaan yang sudah lama beroperasi mempunyai TIC yang berbeda dengan perusahaan yang belum lama beroperasi.

Untuk sistem produksi, uji MANOVA menunjukkan bahwa nilai signifikansi Wilks' lambda 0,301 (> 0,05). Hal ini mencerminkan bahwa tidak terdapat perbedaan TIC yang signifikan terhadap sistem produksi. Sehingga, perusahaan yang menerapkan sistem produksi make to stock, job order dan gabungan dari keduanya memiliki TIC yang sama baiknya.

Uji MANOVA untuk orientasi pasar menghasilkan nilai signifikansi Wilks' lambda 0,784 (> 0,05). Hasil ini berarti bahwa tidak terdapat perbedaan TIC yang signifikan terhadap orientasi pasar. Dapat disimpulkan bahwa walaupun perusahaan mempunyai orientasi pasar dalam negeri, ekspor atau gabungan, TIC mereka akan sama. 
Secara keseluruhan, hasil uji MANOVA menunjukkan bahwa hanya ada satu karakteristik perusahaan yang mempengaruhi TIC, yaitu usia perusahaan. Ada beberapa justifikasi untuk hasil ini. Kinerja perusahaan akan meningkat seiring dengan bertambahnya usia, karena perusahaan yang lebih lama beroperasi akan memiliki ukuran yang lebih besar (karena jumlah karyawan semakin banyak), tingkat produktivitas yang terus meningkat dan laba yang lebih tinggi (Coad dkk., 2010). Tentu saja hal tersebut memungkinkan perusahaan untuk melakukan TIC lebih baik.

Tabel 3. Hasil Uji MANOVA TIC Terhadap Karakteristik Perusahaan

\begin{tabular}{ccccc}
\hline Karakteristik Perusahaan & Effect & Value & F & Sig. \\
\hline Jumlah Karyawan & Wilks' Lambda & 0,000 & 1,558 & 0,291 \\
Usia Perusahaan & Wilks' Lambda & 0,000 & 5,325 & 0,016 \\
Sistem produksi & Wilks' Lambda & 0,000 & 2,774 & 0,301 \\
Orientasi pasar & Wilks' Lambda & 0,003 & 0,634 & 0,784 \\
\hline
\end{tabular}

Temuan ini mirip dengan hasil studi UKM alas kaki di Surabaya yang menyatakan bahwa usia perusahaan mempengaruhi TIC secara positif dan signifikan (Rinawiyanti dan Lianto, 2016). Tetapi, temuan ini sedikit berbeda dengan studi sebelumnya yang menyatakan bahwa usia perusahaan tidak berpengaruh terhadap TIC UKM alas kaki di Mojokerto (Lianto dkk., 2015).

\section{Uji Crosstabulatiton (crosstabs) pada TIC}

Berdasarkan hasil uji MANOVA, kemudian dilakukan analisis crosstabs untuk mengetahui lebih detil hubungan usia perusahaan dengan variabel TIC dengan hipotesis sebagai berikut:

$\mathrm{H}_{0}$ : Tidak terdapat hubungan antara usia perusahaan dengan variabel TIC.

$\mathrm{H}_{1}$ : Terdapat hubungan antara usia perusahaan dengan variabel TIC.

Berikut merupakan ringkasan penjelasan mengenai hasil uji crosstabs pada beberapa variabel dengan nilai Pearson chi-square di bawah 0,05 (Field, 2009), yang berarti bahwa variabel tersebut memiliki hubungan terhadap usia perusahaan.

1. Variabel "Adanya bagian R \& D secara formal" (Pearson chi-square $=0,000$ ). Perusahaan alas kaki yang masih baru (usianya kurang dari lima tahun) tidak terlalu mementingkan ada tidaknya bagian $R \& D$. Karena mereka hanya berorientasi pada pesanan yang didapatkan (job order), maka mereka sebisa mungkin mendapatkan pesanan supaya perusahaan dapat berjalan dengan menghasilkan produk sesuai pesanan. Sebaliknya, perusahaan yang telah lama beroperasi menyadari pentingnya $\mathrm{R} \& \mathrm{D}$. Mereka umumnya telah memiliki pesanan yang tetap sehingga dapat berfokus pada pengembangan produk, proses dan sistem produksi untuk meningkatkan keunggulan kompetitif.

2. Variabel "Mesin produksi modern" (Pearson chi-square=0,014). Hasil uji crosstabs juga menunjukkan bahwa semakin lama perusahaan beroperasi maka mesin produksi yang dimiliki akan lebih modern. Mesin yang lebih modern tentunya dapat meningkatkan efisiensi dan produktivitas.

3. Variabel "Pengaturan lantai produksi" (Pearson chi-square=0,018). Semakin lama perusahaan beroperasi maka pengaturan lantai produksi akan lebih tepat dan baik. Perusahaan yang baru biasanya belum memiliki pesanan yang tetap. Berbeda dengan perusahaan yang telah lama beroperasi, mereka sudah mempunyai pesanan yang tetap dan 
teratur. Sehingga, perusahaan cenderung untuk mempertimbangkan pengaturan lantai produksi untuk menunjang efisiensi proses produksi.

4. Variabel "Ada merek produk sendiri" (Pearson chi-square=0,04). Usia perusahaan juga berpengaruh pada merek produk sendiri. Semakin lama perusahaan beroperasi, maka semakin besar kemungkinan perusahaan untuk memiliki merek produk sendiri, yang bisa menguatkan keberadaan mereka di pasar.

5. Variabel "SOP" (Pearson chi-square=0,025). Perusahaan yang telah lama beroperasi lebih cenderung untuk mempunyai standar operasional prosedur (SOP) yang lebih baik, karena pembuatan dan perbaikan SOP membutuhkan waktu yang cukup lama.

\section{Simpulan}

Dari studi yang dilakukan pada industri alas kaki menengah dan besar di Jawa Timur, didapatkan kesimpulan sebagai berikut. 30 responden yang disurvey merepresentasikan bahwa mayoritas industri alas kaki menengah dan besar di Jawa Timur adalah industri besar dengan jumlah karyawan lebih dari 100 orang. Sebagian besar telah beroperasi lebih dari 15 tahun dan mempunyai sistem produksi kombinasi (gabungan antara job order dan make to stock). Mayoritas industri alas kaki menengah dan besar di Jawa Timur memproduksi sandal dan sepatu dengan orientasi pasar kombinasi antara domestik (dalam negeri) dan ekspor. Industri alas kaki menengah dan besar di Jawa Timur didominasi oleh penanaman modal dalam negeri dan sebagian besar telah mampu menghasilkan lebih dari 30 macam produk.

Pengukuran TIC menunjukkan bahwa dimensi dengan nilai rata-rata tertinggi adalah manufacturing capability, organization capability, strategic planning capability dan $R \& D$ capability. Beberapa saran perbaikan diberikan untuk meningkatkan TIC di tiga dimensi dengan nilai rata-rata di kategori sedang, yaitu learning capability, marketing capability dan resource allocation capability

Hasil uji MANOVA menunjukkan bahwa usia perusahaan berpengaruh terhadap TIC. Berikutnya, uji crosstab mengidentifikasi lima variabel TIC mempunyai hubungan dengan usia perusahaan, yaitu adanya bagian R \& D secara formal, mesin produksi modern, pengaturan lantai produksi, mempunyai merek produk sendiri dan standar operasional prosedur. Hasil uji crosstab menunjukkan bahwa perusahaan yang telah lama beroperasi mempunyai TIC yang lebih baik di kelima variabel tersebut dibandingkan dengan perusahaan yang belum lama beroperasi.

Temuan dari studi ini dapat memberikan gambaran mengenai TIC pada industri alas kaki di Jawa Timur, khususnya pada perusahaan menengah dan besar. Saran-saran yang diberikan dapat menjadi masukan untuk mengembangkan TIC sehingga keunggulan kompetitif industri alas kaki di Jawa Timur dapat ditingkatkan. Perbaikan tidak hanya dilakukan oleh perusahaan, tapi dukungan dan bantuan pemerintah juga diperlukan. Dengan demikian, industri alas kaki mempunyai kapabilitas inovasi teknologi yang semakin bagus, selalu berinovasi dan memanfaatkan teknologi, sehingga dapat bersaing di pasar domestik ataupun global.

Temuan dari studi ini memberikan kesempatan untuk penelitian lebih lanjut. Karena studi ini menggunakan sampel kecil (30 responden), maka penelitian selanjutnya dapat melibatkan responden lebih banyak untuk menghasilkan generalisasi temuan. Studi ini mendapatkan data dari satu sumber (informan), yaitu responden. Penelitian berikutnya bisa melengkapi dengan sumber data yang lain untuk mereduksi bias, misalnya wawancara atau data obyektif, seperti laporan tahunan perusahaan. Selain itu, penelitian lebih lanjut bisa dilakukan untuk mengukur sejauh mana TIC mempengaruhi kinerja inovasi dan kinerja usaha industri alas kaki. 


\section{Daftar Pustaka}

Abereijo, I. O., Ilori, Matthew Oluwagbemiga, Taiwo, Kehinde A. and Adegbite, Stephen Akinade. 2007. Assessment of the capabilities for innovation by small and medium industry in Nigeria. African Journal of Business Management, 1(8), 209-217.

APRISINDO. 2019. More Than 20 Years of Indonesian Footwear Associaction. https://www.aprisindo.or.id/profil-aprisindo/sejarah, diakses 16 Agustus 2020.

Aria, P. 2016. Inilah Industri Yang Rawan Kena Dampak MEA. https://bisnis.tempo.co/read/734434/inilah-industri-yang-rawan-kena-dampakmea/fulldanview=ok, diakses 16 Agustus 2020.

Azubuike, V. M. U. 2013. Technological Innovation Capability and Firm's Performance in New Product Development. Communications of the IIMA, 13(1), 43-55.

Baldwin, J. R. 1999. Innovation, Training and Success. Working Paper Series, Micro Economic Analysis, Division Canada No. 137.

Becheikh, N., Landry, R. j. L., dan Amara, N. A. 2006. Lessons from innovation empirical studies in the manufacturing sector: A systematic review of the literature from 19932003. Technovation, 26, 644-664.

Bryman, A. B., E. 2011. Business Research Methods Third ed.: Oxford University Press.

Chen, Q., Wang, C.-H., dan Huang, S.-Z. 2020. Effects of organizational innovation and technological innovation capabilities on firm performance: evidence from firms in China's Pearl River Delta. Asia Pacific Business Review, 26(1), 72-96.

Coad, A., Segarra A., Teruel M. 2013. Like milk or wine: does firm performance improve with age? Structural Change and Economic Dynamics, 24, 173-189.

Creswell, J. W. 2014. Research design: qualitative, quantitative, and mixed methods approaches Fourth edition. ed.. Thousand Oaks, California: SAGE Publications, Inc.

Disperindag. 2011. Pelaksanaan Kebijakan Pembangunan Industri Jawa Timur. http://rocana.kemenperin.go.id/phocadownload/Forkom_fungsional/pelaksanaan\%20k ebijakan\%20industri\%20di\%20jatim\%20-\%20kadisperindag\%20jatim.pdf, diakses 20 Desember 2012.

Editor. 2017. Produk Tiongkok Merajalela, Industri Alas Kaki Tak Berdaya. https://indopos.co.id/read/2017/10/10/112988/produk-tiongkok-merajalela-industrialas-kaki-tak-berdaya/, diakses 16 Agustus 2020.

Effendi, M. I., dan Kusmantini, T. 2015. The Moderating Effect of Contingency Variables on the Relationship between Formal Strategic Planning and Company Performance. Procedia - Social and Behavioral Sciences, 211, 1132-1141.

Ferdyansyah, D. S., Eko B. 2013. Pola Spasial Kegiatan Industri Unggulan di Propinsi Jawa Timur Studi Kasus: Subsektor Industri Tekstil, Barang Kulit, dan Alas Kaki JURNAL TEKNIK POMITS, 2(1), C31-36.

Field, A. P. 2009. Discovering statistics using SPSS : and sex, drugs and rock ' $n$ ' roll 3rd Edition ed.. London: SAGE Publications Ltd.

Fowler, F. J. 2014. Survey Research Methods Fifth edition. ed.. Los Angeles: SAGE.

Guan, J., dan Ma, N. 2003. Innovative capability and export performance of Chinese firms. Technovation, 23(9), 737-747.

Guan, J. C., Yam, R. C. M., Mok, C. K., dan Ma, N. 2006. A study of the relationship between competitiveness and technological innovation capability based on DEA models. European Journal of Operational Research, 170(3), 971-986. 
Hair, J., Celsi, M., Money, A. H., Samouel, P., dan Page, M. J. 2011. Essentials of Business Research Methods Second ed.. New York, the United States of America: M.E. Sharpe, Inc.

Hasanah, A. 2019. Potensi Ekspor Tinggi, Pemprov Jatim Beri Perhatian Industri Alas Kaki https://rri.co.id/ekonomi/716899/potensi-ekspor-tinggi-pemprov-jatim-beri-perhatianindustri-alas-kaki, diakses 16 Agustus 2020.

Huber, G. P., dan Power, D. J. 1985. Retrospective reports of strategic-level managers: Guidelines for increasing their accuracy. Strategic Management Journal, 6(2), 171180.

Inayati, T. 2018. Strategi Manajemen SDM, Orientasi Pasar, dan Kinerja UKM. Jurnal Organisasi dan Manajemen, 14(2), 120-131.

Indonesia, P. I. 2019. RI Andalkan 5 Produk Unggulan. https://indonesia.go.id/narasi/indonesia-dalam-angka/ekonomi/ri-andalkan-5-produkunggulan, diakses 7 April 2020.

Johnson, R. B., dan Onwuegbuzie, A. J. 2004. Mixed Methods Research: A Research Paradigm Whose Time Has Come. Educational Researcher, 33(7), 14-26.

Karagouni, G., dan Papadopoulos, I. 2007. The Impact of Technological Innovation Capabilities on the Competitiveness of a Mature Industry. Management of International Business dan Economic Systems, 1(1), 17-34.

Karba'a, T. 2010. Ekspansi Produk China Memberi Tekanan Kepada Produk Lokal. https://news.detik.com/opini/d-1362668/ekspansi-produk-china-memberi-tekanankepada-produk-lokal, diakses 16 Agustus 2020.

Kemenperin. 2003. Pembangunan Sentra Industri Persepatuan DI Sidoarjo, Jawa Timur. https://kemenperin.go.id/artikel/594/Pembangunan-Sentra-Industri-Persepatuan-DISidoarjo,-Jawa-Timur, diakses 16 Agustus 2020.

Kemenperin. 2018. Pangsa Pasar Lampaui 4 Persen, Industri Alas Kaki Peringkat Ke-5 Dunia. $\quad$ http://kemenperin.go.id/artikel/17605/Pangsa-Pasar-Lampaui-4-Persen,Industri-Alas-Kaki-Peringkat-Ke-5-Dunia, diakses 16 Agustus 2020.

Kemenperin. 2019. Indonesia Produsen Alas Kaki Terbesar Keempat Di Dunia. https://kemenperin.go.id/artike1/20539/Indonesia-Produsen-Alas-KakI-TerbesarKeempat-Di-Dunia, diakses 16 Agustus 2020.

Kim, E., Nam, D.-i., dan Stimpert, J. L. 2004. Testing The Applicability of Porter's Generic Strategies in The Digital Age: A Study of Korean Cyber Malls. Journal of Business Strategies, 21(1), 19-45.

Lang, T. M., Lin, S. H., dan Vy, T. N. T. 2012. Mediate effect of technology innovation capabilities investment capability and firm performance in Vietnam. Procedia - Social and Behavioral Sciences, 40, 817-829.

Lianto, B., Rinawiyanti, E. D., dan Soeharsono, F. 2015. Studi Keterkaitan Kapabilitas Inovasi dan Kinerja Inovasi UKM Alas Kaki di Mojokerto. Jurnal Inovasi dan Kewirausahaan, 4(1), 9-20.

Lianto, B., Wahyudi, R. D., Rinawiyanti, E. D., dan Herninda, A. 2015. Assesment of Innovation Process Capability-Based on Innovation Value Chain Model in East Java Footwear Industry. The Asian Journal of Technology Management, 8(2), 132-150.

Miller, J. G., dan Roth, A. V. 1994. A taxonomy of manufacturing strategies. Management Science, 40(3), 285.

Moohammad, A. Y., Nor'Aini, Y., dan Kamal, E. M. 2014. Influences of Firm Size, Age and Sector on Innovation Behaviour of Construction Consultancy Services Organizations in Developing Countries. Business Management Dynamics, 4(4), 1-9. 
Nurdin, E. 2019. Industri Alas Kaki: Ketika Prospeknya Semakin Cerah. Solusi, 26-30.

Pallant, J. F. 2005. SPSS survival manual: a step by step guide to data analysis using SPSS for Windows Version 12 2nd ed.. Crows Nest, N.S.W.: Allen dan Unwin.

Paraschiv, D. M., Nemoianu, E. L., Langa, C. A., dan Szabó, T. 2012. Eco-Innovation, Responsible Leadership And Organizational Change For Corporate Sustainability Amfiteatru Economic, 14(32), 404-419.

Pramayani, A. A. S. D. I., dan Adnyani, I. G. A. D. 2018. Pengaruh Pemberdayaan, Perilaku Inovatif, dan Motivasi Kerja Terhadap Produktifitas Kerja Karyawan Bumbu Bali Restoran Tanjung Benoa Badung, Bali INOBIS: Jurnal Inovasi Bisnis dan Manajemen Indonesia, 2(1).

Pratiwi, D. A. 2020. Pemerintah Tempa 500 Peserta Diklat 3in1 Industri Alas Kaki. https://akurat.co/ekonomi/id-988664-read-pemerintah-tempa-500-peserta-diklat-3in1industri-alas-kaki, diakses 16 Agustus 2020.

Rajapathirana, R. P. J., dan Hui, Y. 2018. Relationship between innovation capability, innovation type, and firm performance. Journal of Innovation dan Knowledge, 3(1), 44-55.

Ramadhani, P. I. 2020. Kemenperin Ciptakan Aplikasi Jejaring untuk Industri Alas Kaki. https://www.liputan6.com/bisnis/read/4327039/kemenperin-ciptakan-aplikasijejaring-untuk-industri-alas-kaki, diakses 16 Agustus 2020.

Rianto, Y., Triyono, B., dan Laksani, C.S. 2006. Studi faktor-faktor determinan kemampuan inovasi UKM. Jakarta: LIPI Press.

Rinawiyanti, E. D., dan Lianto, B. 2016. Pengaruh Karakteristik UKM pada Kapabilitas Inovasi dan Kinerja Inovasi UKM Studi Kasus pada Sentra IKM Alas Kaki Jawa Timur. Journal of Industrial Engineering dan Management Systems, 9(2), 109-122.

Rinawiyanti, E. D., Lianto, B., Fitari, dan Silvia, D. 2018. How Capable are Small and Medium Enterprises in Conducting Innovation? Paper presented at the 3rd AsiaPacific Research in Social Sciences and Humanities Universitas Indonesia Conference APRISH 2018, Jakarta, Indonesia.

Ruel, E. E. a., Wagner, W. E., dan Gillespie, B. J. 2016. The practice of survey research : theory and applications. Thousand Oaks, CA: Sage Publications, Inc.

Shan, J., dan Jolly, D. R. 2010. Accumulation of Technological Innovation Capabilities and Competitive Performance in Chinese Firm: a Quantitative Study. IAMOT 2010, Cairo, Egypt.

Siyamtinah, Sulistyo, H., dan Rahmani, E. 2011. Model Peningkatan Kinerja Melalui Kapabilitas Inovasi pada UKM di Semarang. Paper presented at the Seminar Nasional Ilmu Ekonomi Terapan 2011.

Smit, J. 2015. The Innovation Value Chain and Adaptability of Organizations. Journal of International Technology and Information Management, 24(3), 57-73.

Swink, M., Narasimhan, R., dan Kim, S. W. 2005. Manufacturing Practices and Strategy Integration: Effects on Cost Efficiency, Flexibility, and Market-Based Performance. Decision Sciences, 36(3), 427-457.

Theodorou, P., dan Florou, G. 2008. Manufacturing strategies and financial performanceThe effect of advanced information technology: CAD/CAM systems. Omega, 36(1), 107-121.

Venkatraman, N. 1989. Strategic Orientation Of Business Enterprises: The Construct, Dimensionality, And Measurement. Management Science, 35(8), 942-962.

Wardani, T. R. 2019. Produksi 1,41 Miliar Pasang Sepatu, Industri Alas Kaki RI Peringkat 4 Dunia. https://economy.okezone.com/read/2019/04/07/320/2040219/produksi-1-41- 
miliar-pasang-sepatu-industri-alas-kaki-ri-peringkat-4-dunia, diakses 16 Agustus 2020.

Widarti, P. 2019. Ekspor Alas Kaki, Jatim Butuh Industri Pendukung. https://surabaya.bisnis.com/read/20190709/532/1122052/ekspor-alas-kaki-jatimbutuh-industri-pendukung, diakses 16 Agustus 2020.

Yam, R. C. M., Guan, J. C., Pun, K. F., dan Tang, E. P. Y. 2004. An audit of technological innovation capabilities in chinese firms: some empirical findings in Beijing, China. Research Policy, 33(8), 1123-1140.

Yam, R. C. M., Lo, W., Tang, E. P. Y., dan Lau, A. K. W. 2011. Analysis of sources of innovation, technological innovation capabilities, and performance: An empirical study of Hong Kong manufacturing industries. Research Policy, 40(3), 391-402.

Yam, R. C. M., Lo, W. L., Tang, E. P. Y., dan Lau, A., K.W. 2010. Technological Innovation Capabilities and Firm Performance. World Academy of Science, Engineering and Technology, 42, 1009-1017.

Yousefi, P., Mohaimani, M., dan Mohaimani, M. 2013. The Effects of Technological Innovation Capabilities on Performance Outcomes in Iran Khodro. Journal of Basic and Applied Scientific Research, 3(9), 648-657. 